\title{
Defending Hierarchy from the Moon to the Indian Ocean: Symbolic Capital and Political Dominance in Early Modern China and the Cold War
}

\author{
Paul Musgrave and Daniel H. Nexon
}

\begin{abstract}
Why do leading actors invest in costly projects that they expect will not yield appreciable military or economic benefits? We identify a causal process in which concerns about legitimacy produce attempts to secure dominance in arenas of high symbolic value by investing wealth and labor into unproductive (in direct military and economic terms) goods and performances. We provide evidence for our claims through a comparative study of the American Project Apollo and the Ming Dynasty's treasure fleets. We locate our argument within a broader constructivist and practicetheoretic understanding of hierarchy and hegemony. We build on claims that world politics is a sphere of complex social stratification by viewing constituent hierarchies in terms of social fields. Our specific theory and broader framework, we contend, provide tools for understanding the workings of power politics beyond military and economic competition.
\end{abstract}

In 1961, President John F. Kennedy committed the United States to "landing a man on the moon and returning him safely to the earth." "Fulfilling that pledge, the Apollo project landed six manned spacecraft on the lunar surface between 1969 and 1972. Yet in 1972 President Richard Nixon terminated the program, scaled back the National Aeronautics and Space Administration's (NASA) budget, and limited US manned space ambitions to near-Earth operations, where they have remained.

We greatly appreciate the helpful feedback provided by David Edelstein, Maia Gemmill, Patrick Thaddeus Jackson, Kathleen McNamara, Iver Neumann, Vincent Pouliot, two anonymous referees, and the editors and staff of International Organization. Previous versions of this article were presented at the 2016 International Studies Association; the 2014 American Political Science Association annual meetings as part of a series of linked panels organized by Aida Hozic, Peter Katzenstein, and Lucia Seybert; a workshop on hierarchy in world politics held at the University of California, San Diego, organized by David Lake, Janice Bially Mattern, and Ayşe Zarakol; and a seminar at the Centre for International Policy Studies at the University of Ottawa organized by Kevin McMillan. We thank participants at these events for their comment and criticisms. Funding for this article was provided by the Norwegian Research Council under the project "Evaluating Power Political Repertoires (EPOS)," project no. 250419.

Editor's note: IO's conflict-of-interest policy ensures that editors do not make decisions on manuscripts written by current or former students, current or former co-authors, or authors at the same institution. This manuscript was accepted by the previous editorial team so no conflict of interest arose.

1. John F. Kennedy, "Special Message to the Congress on Urgent National Needs," 25 May 1961, The American Presidency Project, <http://www.presidency.ucsb.edu/ws/?pid=8151>. 
Several centuries earlier, another powerful government's project of costly expeditions played out similarly. In 1405, the Yongle emperor of China's Ming Dynasty authorized several massive naval expeditions to the Indian Ocean. After a final voyage under the Xuande emperor in 1433, the expeditions ended forever.

For space-exploration advocates, China's decline after the Ming treasure fleets demonstrate what happens to great powers when they stop exploring. ${ }^{2}$ For anti-isolationists in China and elsewhere, the end of the expeditions serves as a marker for the Ming Dynasty's inward turn, supposedly causing China's eventual "century of humiliation" at the hands of more adventuresome Western powers. ${ }^{3}$ Critics contend that the real lesson of the Apollo and treasure-fleet voyages was that they were pointless: "The Chinese ceased voyaging to the coast of Africa for the same reason the United States stopped sending men to the moon-there was nothing there to justify the costs of such voyages." ${ }^{4}$ Yet this more sophisticated argument raises an even larger puzzle: why did either power "go there" in the first place?

In both cases, we argue, leaders embarked on costly endeavors to legitimate their claims to leadership-emperorship or American hegemony. We find little indication that the Ming expected the treasure fleets to yield military or economic awards. Similarly, Kennedy and his advisers saw the Apollo project as a colossal waste of resources if measured in direct economic or military terms. Yet evidence suggests that both leaders made this choice to secure dominance in arenas that they viewed as symbolically critical to leadership and security. For the Yongle emperor-a usurper in an insecure dynasty - that meant demonstrating that other rulers in the "known world" acknowledged their status as his tributaries. For Kennedy, this meant securing a successful "first" in the science-and-technology field to eclipse the Soviet "firsts" like Sputnik and Gagarin's orbit. Kennedy believed continuing failure in this arena threatened American hegemonic leadership. In both cases, when the apparent crises passed-in part because the projects achieved their goals - the projects ended.

We locate this argument within a broader social-constructionist understanding of hierarchy and hegemony. We cash out the wager that world politics is a sphere of complex social stratification ${ }^{5}$ by viewing constituent hierarchies in terms of social fields. The possession of field-relevant capital positions actors in various relations of super- and subordination within fields. ${ }^{6}$ According to hegemonic-order theorists, military and economic capital plays a major role in establishing overall position in political systems - in part because of their greater fungibility, as possessing capital in those fields can also help actors secure privileged positions in other fields.

2. Smith and Davies 2012, 140-41, and Maria T. Zuber testimony before Committee on Science, Space, and Technology, US House of Representatives, 22 September 2011, <https://science.house.gov/sites/ republicans.science.house.gov/files/documents/hearings/092211_Zuber.pdf>.

3. For example, Barr 2012, 45-53; Zakaria 2012, 64.

4. Goldstone 2000, 177.

5. Bially Mattern and Zarakol 2016.

6. See Adler-Nissen 2008; Bourdieu and Wacquant 1992, 101; Pouliot and Mérand 2012. 
Within that general framework, specific fields may-for socially and historically contingent reasons - not only emerge but also take on "outsized" significance in relations of political dominance. Relevant resources - tangible goods, tokens, or even performances-become, in Bourdieu's term, symbolic capital. ${ }^{7}$ The Ming court and the Kennedy administration spent significant economic resources on, respectively, the treasure fleets and the Apollo program precisely to acquire what they saw as symbolic capital critical for maintaining political dominance.

This framework integrates relevant theoretical perspectives and strands of research. Hegemonic-order theories posit that dominant actors craft political order and, in doing so, allocate status and prestige. ${ }^{8}$ These theories imply that dominant actors will seek to legitimate their position, but they face trouble in accounting for, first, when they make exceptionally costly investments in acquiring symbolic capital and, second, the particular kinds of goods and performances that dominant actors pursue. ${ }^{9}$ The cases here-in which dominant actors saw economically and militarily unproductive investments as appropriate responses to critical security threats-prove particularly challenging.

Theories of status competition and conspicuous consumption do expect actors to demonstrate social dominance by purchasing prestige goods or engaging in expensive performances. Still, they often struggle to explain variation-not only among the choice of prestige goods and performances, but also in terms of the relative value of those goods and performances with respect to other forms of capital. Social-constructionist approaches, which stress historically and socially contingent dynamics, help explain this variation. ${ }^{10}$ Turning to field theory synthesizes these insightsand integrates them into more general accounts of hierarchy in world politics. In particular, a focus on social fields provides a way of theorizing how processes of social construction create strategic contexts through which actors pursue power politics.

\section{Hegemony, Hierarchy, and Social Fields}

Recent years have seen the rise — or, more accurately, the reinvigoration — of hierarchycentric scholarship. As Bially Mattern and Zarakol argue, participants hold that "hierarchies are ubiquitous features" of international relations that "generate social, moral, and behavioral dynamics that are different than those created by other arrangements." 11 A focus on hierarchy, they claim, resolves enduring puzzles or overturns existing conventional wisdom. Many attempt to rope together a range of older work and situate it in conversation with emerging research. ${ }^{12}$ For example, Lake

7. Bourdieu 1986.

8. See Gilpin 1981.

9. Go 2008.

10. Gilady 2006, 2017. See also Eyre and Suchman 1996.

11. Bially Mattern and Zarakol 2016, 624.

12. Hobson and Sharman 2005. 
suggests that aspects of American foreign relations become less puzzling when viewed as taking place within a zone of interstate hierarchy. ${ }^{13}$ McDonald argues that the democratic peace is as an artifact of a great-power hierarchy that simultaneously reduces military conflict and produces similar regime types. ${ }^{14}$

What is hierarchy? Social and political systems are hierarchical to the extent that they are stratified along a series of asymmetric rankings or positions. That is, hierarchy refers to any pattern of super- and subordination. Status hierarchies are stratified by rankings of honor and prestige, class hierarchies by economic roles, and so forth. These stratifications matter to the extent that they translate into relations and practices of social dominance. Much of international-relations scholarship-from work on global governance to theories of great-power politics-examines the causes and consequences of various forms of super- and subordination.

Major research agendas-including hegemonic-stability and power-transition theory, world systems theory, dependency theory, and the study of empires-take some kind of international hierarchy as a basic fact of world politics. But, by the 1990s, the focus of theoretical debates in the field generally shifted to the nature and consequences of international anarchy. ${ }^{15}$ This change owed much to the emergence of structural realism as a focal point for theoretical debates. For structural realists, anarchy represents not only the central fact of world politics but also justifies the study of international relations as a distinctive area of inquiry. In Waltz's formulation, "parts of domestic political systems stand in relations of super- and subordination. Some are entitled to command; others are required to obey. Domestic systems are centralized and hierarchic." In contrast, "the parts of international-political systems stand in relations of coordination. Formally, each is the equal of all the others. None is entitled to command; none is required to obey. International relations are decentralized and anarchic." 16

Much hierarchy-centric scholarship makes a critical point: once we shift from assuming anarchy to focusing on patterns of super- and subordination, we need to attenuate - if not abandon - the assumption that relations among states are fundamentally distinctive from relations within them. For example, the absence of a clean distinction between "international anarchy" and "domestic hierarchy" undermines warrants for dismissing the importance of legitimacy and authority in international politics. Theories developed to handle relations among actors in other contexts can be applied to international settings. ${ }^{17}$ Mechanisms and processes that

\section{Lake 2009.}

14. McDonald 2015. See also Barkawi and Laffey 1999.

15. Major exceptions can be found in post-Marxist and critical IR scholarship. See Agathangelou and Ling 2009; Barder 2016; Galtung 1971; Wallerstein 2004. The centrality of anarchy may, in fact, cut off lines of engagement with other fields, according to Baron 2014.

16. Waltz $1979,88$.

17. Butt 2013, 579-80; Cooley 2005; Lake 2009; Nexon and Wright 2007. Scholarly practice often runs ahead of international theory, insofar as productive research traditions-bargaining theories, constructivist theories, and so on-in the field routinely do just that. 
hold within polities may also operate among and across them. ${ }^{18}$ We compare the Apollo program-where interstate concerns involving hegemonic influence and a revisionist power played a key role-to the Ming treasure fleets-where concern involving legitimacy within imperial structures predominated-in part to highlight this implication of hierarchy-centric theory.

\section{Hegemony and Hierarchy}

Focusing on the hierarchical dimensions of world politics generates its own problems. As Donnelly argues, "hierarchy provides almost as poor an account of the structure of international (and national) systems as anarchy. It simply states that the pattern of stratification is not flat." We need an approach that tells us "how a system is stratified-or anything else about the (many and varied) ways in which international systems are structured."19

Hegemonic-order theories offer one solution. They also illustrate the varied character of hierarchy in world politics. Hegemonic-order theory describes a broad class of international hierarchies: those involving a pre-eminent power that manages the relations of subordinate actors. For power-transition theorists, "relations within ... [the] power hierarchy are not anarchical despite the absence of formal rules and enforced international law." 20 Gilpin maintains that world politics are anarchical and hence distinctive from domestic systems, but that "it is possible to identify similarities in the control mechanisms of domestic systems and international systems." 21

Hegemony describes "the mobilization of leadership" to order relations among other actors. ${ }^{22}$ Such understandings of hegemony ${ }^{23}$ involve a polity using its superior economic and military capabilities - its position atop interstate hierarchies in these domains - to create an international order "manifest in the settled rules and arrangements between states that define and guide their interactions." 24 These can involve rules and norms of conduct, the topography of formal international institutions, the (related) allocation of status and prestige, and even who "counts" as an international actor. $^{25}$

These elements of international order highlight additional patterns of hierarchy, such as those created when actors vary in their compliance with norms of conduct, ${ }^{26}$ garner differential status through the extent that they demonstrate their

18. Cooley 2005; Hobson and Sharman 2005;Wendt and Friedheim 1995.

19. Donnelly 2015, 419-20.

20. Lemke 2002, 22.

21. Gilpin 1981, 28.

22. Barder 2016.

23. On a major alternative-neo-Gramscian hegemon-see Burnham 1991.

24. Ikenberry 2011, 12. See also Butt 2013. Lake 2009 distinguishes his account of hierarchy from classic hegemonic-stability theory.

25. Gilpin 1981, 29-38.

26. Adler-Nissen 2014; Towns 2009; Zarakol 2011. 
military prowess, ${ }^{27}$ or enjoy positions of super- and subordination in international forums. ${ }^{28} \mathrm{As}$ we noted, any form of differentiation-from national performance on educational standards to the possession of culturally significant landmarks-can become, or contribute to, politically relevant hierarchies. Hegemonic ordering operates, in no small measure, by influencing both how much these forms of differentiation matter and by shaping the distribution of relevant assets, relations, and practices.

Hegemons are not necessary for international order. International order can be created and upheld by great-power cartels or generalized consent among states-or as emergent properties of the interaction of polities. ${ }^{29}$ Even in hegemonic systems, international order enjoys relative autonomy from the leading power. Thus, hegemony describes a specific form of leadership —one that rests on occupying a position of some combination of military and economic superiority - that helps generate, interacts with, and shapes other patterns of hierarchy.

\title{
Social Fields, Capital, and Hierarchy
}

Establishing the relationship between hegemony and hierarchy clarifies, without resolving, Donnelly's concern about mapping hierarchies. How to proceed? Some deploy network-analytic measures to tease out variation in prestige hierarchies or forms of political domination. ${ }^{30} \mathrm{We}$ adopt another alternative: treating world politics as composed of a variety of social fields. ${ }^{31}$ Patterns of super- and subordination within these fields reflect the possession of field-relevant capital-that is, resources and performances that confer status and commensurate power within a particular social context. ${ }^{32}$ Those with more field-relevant capital occupy a higher position than those with less. Various forms of capital serve as both the objective and currency of power-in Berling's terms, capital is "the most important criteria for defining an agent's position in the hierarchy in a field." 33

Bourdieu defines capital as "accumulated labor (in its materialized form or its 'incorporated' embodied form which, when appropriated on a private, i.e., exclusive, basis by agents or groups of agents, enables them to appropriate social energy in the form of reified or living labor." 34 The best known typology of capital involves Bourdieu's broad tripartite distinction between economic capital, social capital, and cultural capital, ${ }^{35}$ although he also added new kinds as fitted his empirical concerns, such as "academic capital." Broader forms of capital have subtypes, or

\author{
27. Renshon 2016. \\ 28. Pouliot 2011. \\ 29. Bukovansky 2002; Koivisto and Dunne 2009; Reus-Smit 1997 \\ 30. Nexon and Wright 2007; Renshon 2016. \\ 31. Go 2008 . \\ 32. Bourdieu 1986; Bourdieu and Waquant 1992, 98. \\ 33. Berling 2012, 455. See also Bourdieu and Wacquant 1992, 101. \\ 34. Bourdieu 1986, 81. \\ 35. Bourdieu 1986.
}


subspecies—-such as derivatives, stocks, and cash for economic capital—whose value varies in time and space. Although we can understand the relationships produced by fields and the allocation of capital in general terms, the social fields that define any particular kind of capital are historically and socially contingent: we can only know them through empirical study.

Field-theoretic approaches fit well with social-constructivist and related sensibilities. ${ }^{36}$ In English School terms, much of world politics takes place within international hierarchical "societies" that locate actors in positions of super- and subordination. ${ }^{37}$ These locations are not driven solely by military and economic capabilities, but also by the possession of other socially valued assets, such as cultural capital, social capital in the form of relationships with other actors, and the ability to engage in related performances. As Adler-Nissen argues, "a field is a historically derived system of shared meanings, which define agency and make action intelligible and the agents in a field develop a sense of the social game. The stratification of a field is based on different forms of capital ... and the efficacy of the capital depends on the contexts where it is used." 38

Field theory treats agents as behaving strategically with respect to the socially constituted field in which they operate. Fields each have "their own 'stakes' around which contestants struggle and jostle for position ... agents are conditioned in their strategic behavior by their location in the competitive, game-playing character of the field." They "compete, collude, negotiate, and contest for position." ${ }^{39}$ Thus, "field is an inclusive concept orienting analysts to both objective positions and cultural meaning, to both objective positions and cultural stances." ${ }^{40}$ For example, in modern academic life publications, citations, the ranking of home institutions, and other familiar factors constitute subspecies of academic capital.

With respect to world politics, international-relations scholars generally assume, reasonably, that, in an overarching field of interstate relations (the "international system"), military and economic resources serve as critical field-relevant capital. But those are not the only possible metrics. Towns shows that actors can also differentiate themselves through "standards of civilization" marked by, for instance, the socio-political position of women. ${ }^{41}$ Similarly, racial hierarchies in world politics reflect the construction of membership in different "racial groups" as field-relevant capital for states and other actors..$^{42}$ The possession of colonies-and the performance of imperial management-became important capital in the field of great-power competition during the nineteenth century. ${ }^{43}$

36. See Finnemore 1996; McCourt 2016.

37. Bull 1977; Buzan 1993; Clark 2009.

38. Adler-Nissen 2008, 668.

39. Savage, Warde, and Devine 2005, 39.

40. Go and Krause 2016, 9.

41. Towns 2009.

42. See Vitalis 2015; Vucetic 2011.

43. Barnhart 2016. 
Particular capital endowments often become important to position in particular fields via their investment with specific symbolic importance. According to Zhang, "objective capital can be expressed and represented through symbolic capital, as it will always have a symbolic form." But "symbolic capital can exist independently of objective capital: for instance, the word 'progress' may carry symbolic capital, but by itself it has no form of objective capital." When "the symbolic capital contained in the term 'progress' is married to something objective, such as tools (a form of economic capital), social networks (social capital), or specific building styles (cultural capital), this infusion of symbolic capital will change their nature and increase their capital." 44 The constitution of particular weapons-systems-say, nuclear weapons-as "prestige goods" involves the translation of particular subspecies of military capital into symbolic capital representing great-power status and attendant technological prowess. ${ }^{45}$

Field-theoretic approaches regard world politics as composed of multiple forms of stratification. There are as many potential hierarchies as there are social fields; the same actors may occupy different positions in different social fields. Actors may try to create fields - or subfields-in which they enjoy advantages in field-relevant capital. For example, some states punch above their economic and military weight in international sporting fields, while others underperform in various diplomatic fields. ${ }^{46}$ The logic of "status compensation" strategies entails wagering that states may deal with status immobility in some fields by seeking a superordinate position in others. ${ }^{47}$

Some fields prove enduring, others ephemeral. Capital that once enjoyed great symbolic importance for competition among great powers and great-power aspirants-diplomatic priority at the papacy, the possession of colonies-loses its significance as the terms of field-relevant capital shifts. The relationship between fields also varies over time. In Bourdieusian terms, the "rate of exchange" between different forms of capital is not only mutable, but also shapes and reflects the hierarchy of fields. The resulting hierarchy-how fields relate to one another-constitutes an important dimension of international order.

This creates analytic difficulties. How do we identify a field? How do we map its boundaries? There "are often several fields that intersect or relate, but they are [still] relatively distinct." ${ }^{48}$ Capital in one field—say, science and technology—can become important in another field because of its fungibility, or it can emerge as symbolic capital relevant to that other field. For Bourdieu, "the limit of a field is the point where the effects of its actors and institutions cannot be found," which places a

44. Zhang 2004, 7.

45. See Eyre and Suchman 1996.

46. Sometimes actors are sufficiently entrenched that they do not mind falling short in other fields. Harvard cares much less than other institutions when its sports teams fare poorly in intercollegiate play, since its position in other fields guarantees it hegemonic or quasi-hegemonic influence.

47. See Larson and Shevchenko 2010.

48. Go and Krause 2016, 10. 
high burden on careful empirical analysis. ${ }^{49}$ This is harder to operationalize in studies of world politics than in well-bounded social spaces, such as community theater troupes or video-gaming guilds.

Such challenges are most pressing for attempts to catalog or schematize the universe of fields in world politics. This is not our aim here. We take up the more limited task of identifying the existence of relevant fields, the nature of field-relevant capital, and why they mattered to the maintenance of legitimate leadership. Thus, in the Apollo case, we provide evidence that, first, American decision makers perceived a distinctive field of science-and-technology competition; second, space constituted a critical subfield of that competition; and third, that important audiences and rivals agreed with those assessments..$^{50}$ In the Ming case, we provide circumstantial evidence consistent with these claims and inconsistent with other plausible arguments. But there we have the advantage of being able to point to long-standing understandings of field-relevant capital for establishing the legitimacy of individual and dynastic rule.

\section{Hegemony and Social Fields}

Hegemonic-order theory's central propositions translate into field-theoretic terms. ${ }^{51}$ The tenets of hegemonic-order theory presuppose at least one international fieldakin to what Go calls a "global field" 52 — constituted by the distribution of economic and military capital..$^{53}$ These forms of capital are sufficiently fungible that they allow for the "purchase" - or accumulation — of other assets, such as diplomatic, social, and cultural capital. Hence, when a single actor garners a large-enough quantity of (some combination of) military and economic capital, it can then use that superordinate position to reshape fields.

A dominant actor may do so deliberately - for instance, by rewarding greater conformance with liberal democratic governance norms and thus transform markers of liberal democracy into symbolic capital. Or it may structure international organizations so that holding certain positions-such as a seat on the United Nations Security Council—becomes a form of diplomatic capital that states ultimately struggle over. Or it may do so inadvertently. For example, a leading actor may create such a close association between possessing aircraft carriers and great-power status that some states decide to pursue them for reasons beyond military efficacy. ${ }^{54}$

49. Nexon and Neumann 2017.

50. See the online appendix for more on their historical development.

51. For a more comprehensive treatment, see Nexon and Neumann 2017.

52. Go 2008.

53. In most hegemonic-order theories, economic capital is the bedrock for military capital. Hence, uneven growth provides the primary motor for power transitions, but military capital remains more salient for the immediate balance of power. In turn, the deployment of these capabilities to order international politics derives additional "material benefits"- that is, as long as the hegemon isn't overextended, it begets additional economic and military capital. See Lemke 2002, 22.

54. Nexon and Neumann 2017; Pu and Schweller 2011. 
Such dynamics can manifest in terms of specific performances. Consider Lake's understanding of "symbolic obeisance" as "costly acts that do not involve direct compliance with commands but are nonetheless public, often collective displays of submission that acknowledge and affirm the authority of the ruler." ${ }^{55}$ For Lake, such acts provide evidence of international hierarchy. Thus, when small states committed to provide military resources to the International Security Assistance Force (ISAF) in Afghanistan, they signaled to the US that they accepted its superordinate position. In practice, as field theory would expect, such behaviors also followed an instrumental and strategic logic. For weaker states, they provided a way to seek higher status in the eyes of Washington, which might later lead to economic, military, or diplomatic support. ${ }^{56}$ Or consider the politics of legitimacy in early modern Korea and its connection to Chinese suzerainty, and the use of "ritualized" unequal interaction to sustain that relationship. ${ }^{57}$

Conceptualizing world politics as an arena of social fields does not exhaust all aspects of political order-international or otherwise — but it does provide important analytical leverage. Order finds reflection in the nature of fields, the relationship among them, the terms of exchange of field-relevant capital and, importantly, the complex hierarchies they generate. Actors compete, collude, and jostle within those fields, attempt to change their terms and relationship, or even create new ones.

\section{Dominant Actors and the Pursuit of Symbolic Assets}

Taken together, the discussion implies that actors who sit atop social hierarchies can remain bound by those hierarchies. ${ }^{58}$ Thus, we propose that:

Proposition 1: Superordinate actors will invest in acquiring field-relevant capital connected to political dominance. During periods of acute status uncertainty or ambiguity, ${ }^{59}$ they may even divert significant military or economic capital to accrue economically and militarily unproductive, but symbolically valuable, assets.

This proposition parallels Barnhart's discussion of European powers' acquisition of African colonies in the late nineteenth century. She argues that "many important, seemingly puzzling instances of international behavior are best understood largely as assertions of status, often at the cost of immediate strategic or material interests" 60

55. Lake 2009, 165.

56. American officials sometimes told countries seeking closer ties to the US to contribute, even in token ways, to ISAF. Cooley and Nexon 2016.

57. Lee 2013, 2016.

58. For example, Ottoman rulers long practiced fratricide to secure the throne rather than attempt to rewrite succession rules. See Barfield 1989, 134-38.

59. On status ambiguity as a source of conflict, see Volgy and Mayhall 1995; Wohlforth 2009.

60. Barnhart 2016, 385. 
and that "states are likely to engage in status competition if their status has been called into question by an instance of disrespect or by a humiliating event ... to signal that they possess characteristics and capabilities that distinguish them from lesser powers" and to demonstrate that they can "exercise the prerogatives associated with their desired status."61

We propose a more general account. The underlying dynamics may spring from humiliation or an affront, but more calculating, strategic agendas may predominate. As Go argues, "as powerful states seek symbolic capital to win 'trust,' they do so through ... 'strategic' and 'pragmatic' legitimacy, aiming for symbolic capital as a strategy of power amidst their struggle in the field."62

We further argue that:

Proposition 2: The nature of the capital that actors pursue depends on the interrelationship of social fields. That is, attempts to legitimate dominance normally involve the acquisition of field-relevant capital, which is itself often historically and socially contingent.

Many scholars argue that actors will engage in policies — and costly ones—designed to secure or enhance their standing and hence their claim to legitimate dominance over other actors. ${ }^{63}$ Others argue that states divert resources into highly visible goods as a form of "conspicuous consumption." $64 \mathrm{Pu}$ and Schweller note that "some projects" including "space programs" are "intended as costly signals of great-power status, for they require enormous capabilities and resources that most states do not possess." 65 Early argues that "space capabilities" serve "as important symbols of national pride and indicators of status to other countries in the world."66 Gilady argues that the "high cost of 'Big Science' turns it into a credible test of status by imposing considerable intrinsic restrictions that work as effective gatekeepers." 67

Existing approaches sometimes struggle with variation in the relative importance of different assets - capital—for social dominance and hierarchy. Thus, they often point to invariant reasons that a form of capital matters, or invoke the characteristics and assets of leading powers. ${ }^{68}$ But these invariant reasons explain why states expend resources on some enormously expensive projects but not others. Classifying such expenditures as simple waste or extravagance also undersells the motivations at work if such projects provide not simply markers of status but also strategies of addressing perceived existential threats.

61. Ibid., 386 .

62. Go 2008, 208.

63. Onea 2014.

64. Gilady 2006, 5-12; Pu and Schweller 2011, 151.

65. Pu and Schweller 2011.

66. Early 2014, 56. On the distribution of space capabilities during the Cold War, see Peterson 1997, $245-46$.

67. Gilady 2006, 243. See also Gilady 2017, 126.

68. For an elaboration of this point, see Gilady 2006, 26-30 and 2017, 26-29. 
Field-theoretic approaches, however, expect that particular projects acquire such importance only to the degree that they become "infused" with symbolic significance-and that depends on dynamics within and across fields. ${ }^{69}$ This can result from long-standing and deeply institutionalized forces-or reflect more contingent and short-lived perceptions of dominant actors. The "largely arbitrary reasons why some yardsticks gain political prominence ... stems from contingent politics and practices."70 These conditions may be difficult to specify ex ante, but they are not random: they emerge from the content of fields and the conduct of actors who inhabit them. Thus, we can expect to see similar effects with respect to deeply sedimented and more ephemeral fields and field-relevant capital.

Finally, we address a tendency to focus on revisionist challengers or second-tier states. Such work implicitly assumes that hegemons and other superordinate actors are "field makers" rather than "field takers." But although leaders—such as militarily and economic dominant actors_-exercise some ability to shape other fields, that ability remains limited. They find it comparatively less expensive to "purchase" assets that fit within existing fields than to use, say, economic and military capital to rewrite those fields. Moreover, dominant actors face significant risk if they attempt to do so. They owe their position of social dominance to having accrued significant capital under the existing rules of the game. Changing the basic terms of social priority-turning revisionist against their own order-is an extremely risky move. Holding that leaders can rewrite the rules of the game at will assumes that dominant actors can somehow stand outside their social habits, practices, and dispositions. In some cases, trying to overhaul the rules of the game will even seem simply implausible.

This suggests that:

Proposition 3: Superordinate actors - whether hegemons, empires, or their leaderswill find themselves limited with respect to how they maintain and pursue social dominance through the acquisition of field-relevant capital in general, and symbolic capital in particular.

Rulers cannot usually simply abandon long-standing criteria of legitimacy without risking political instability or even overthrow. Leaders of hegemonic states often face similar constraints with respect to their position in fields of great-power competition.

\section{Case Justification}

We first surmised a link between our cases because of their frequent connection in popular and even scholarly contexts. However, our justification for studying them 
derives from specific methodological and theoretical considerations. We pursue an "uncommon foundations" strategy of "identifying causal mechanisms in widely different cases."71 Our cases involve enormous differences. Even ignoring cultural, technological, institutional, regime, military, economic, and social differences, the United States of the 1950s and 1960s was a sovereign state facing a significant international competitor across multiple international fields. The Yongle emperor's greatest challenges emerged from perceptions within the empire that his rule was illegitimate. If similar analytics and causal mechanisms provide explanatory leverage despite these differences, then the uncommon characteristics of the case give us greater analytic confidence. ${ }^{72}$

Despite such surface differences, both involve political hierarchies with transnational dimensions. The Yongle emperor and President Kennedy contended with both "domestic" and "international" audiences. Ming rule simultaneously encompassed both a state-like core but also a broader network of tributary states and peripheral areas. Treating even Ming "domestic" politics as akin the domestic politics of a sovereign-territorial state is a category error: neither Ming authority in particular, nor imperial strategies of rule in general, reflect a clean division between "international" and "domestic" politics. ${ }^{73}$ The hierarchical nature of the Western order circa 1961 meant that President Kennedy, like other postwar American presidents, played a similar dual role as both the chief executive of the US government and the titular "leader of the Free World" sitting atop a globe-spanning network of alliances and partnerships. ${ }^{74}$ Some even compare the two systems. ${ }^{75}$

However one comes down on the specifics, the cases help vet a key wager of hierarchy-centric scholarship: that we should be able to find similar dynamics across "domestic" and "international" hierarchies. Table 1 summarizes the key conceptual and theoretical elements of the cases.

\section{Main Alternative Explanations}

The most plausible rival theories for why states invest massive amounts of resources into given performances derive from military security or economic incentives. The

71. McAdam, Tarrow, and Tilly 2001, 83. See also Hui 2005, 8.

72. See Nexon 2009, 65; Tilly 1995, 1997.

73. See Musgrave and Nexon 2013; Nexon and Wright 2007.

74. On the rhetorical importance of "the leader of the Free World," see McNamara's comments during the Cuban Missile Crisis at FRUS Volume 11, Document 34 ("Minutes of the 505th Meeting of the National Security Council") or routine uses of the phrase, such as the Portuguese foreign minister's declaration that "Portugal had the highest respect and consideration for the President not only as the leader of the Free World but also as a person and an individual"; FRUS Vol. 13, Western Europe and Canada, Document 354, ("Memorandum of Conversation," 2 August 1963). The "free world" was not just a poetic metaphor but a routine part of the bureaucratic imaginary. See, for instance, National Security Action Memorandum 3, Bunkering of Free World Ships Under Communist Chinese Charter, Papers of John F. Kennedy. Presidential Papers, National Security Files, JFKNSF-328-004.

75. Khong 2013. 


\section{TABLE 1. Case summaries}

\begin{tabular}{|c|c|c|c|c|c|c|}
\hline Case & $\begin{array}{l}\text { Superordinate } \\
\text { Actor }\end{array}$ & Contested Fields & Key Symbolic Capital & Audiences/Priority & Orientation of Projects & Reasons for Termination \\
\hline $\begin{array}{r}\text { Treasure } \\
\text { Fleets }\end{array}$ & Ming Emperor & Dynastic politics & $\begin{array}{l}\text { Evidence of obeisance } \\
\text { from foreign rulers }\end{array}$ & $\begin{array}{l}\text { 1. Core selectorate } \\
\text { 2. Broader empire } \\
\text { 3. Existing and poten- } \\
\text { tial tributary rulers }\end{array}$ & $\begin{array}{l}\text { Core-centric: } \\
\text { peripheral hierarchy a } \\
\text { source of legitimacy in } \\
\text { the core }\end{array}$ & $\begin{array}{l}\text { Effort undermines opponents of the ruler } \\
\text { Dynastic succession renders usurpation crisis } \\
\text { less urgent } \\
\text { New impetuses for expeditions quashed }\end{array}$ \\
\hline $\begin{array}{l}\text { Project } \\
\text { Apollo }\end{array}$ & United States & $\begin{array}{l}\text { Science and } \\
\text { technology; } \\
\text { space in } \\
\text { particular }\end{array}$ & "Firsts" in space & $\begin{array}{l}\text { 1. Third world } \\
\text { 2. Core allies } \\
\text { 3. Americans }\end{array}$ & $\begin{array}{l}\text { Pericentric: } \\
\text { legitimating hierarchy } \\
\text { over/in periphery central } \\
\text { security concern. }\end{array}$ & $\begin{array}{l}\text { US wins the moon race } \\
\text { Détente reduces symbolic importance } \\
\text { of science-and-technology field for US } \\
\text { hegemony }\end{array}$ \\
\hline
\end{tabular}


Ming treasure fleets' close relationship to the imperial military and the presumed dual-use nature of much space exploration technology in the US case might supply military justifications for such expenditures. Commerical and economic incentives might have mattered, such as Chinese merchants' interests in expanding trade routes or technological spinoffs from lunar exploration. In either case, symbolic correlates would provide, at best, secondary explanations. Other alternatives include arguments from national identity, rent-seeking, and idiographic factors. We consider these in the appendix, where we also provide additional evidence for our explanation and the rival ones we discuss.

\section{Case Methodology}

We deploy process-tracing methodology. ${ }^{76}$ In its Bayesian reformulation, process tracing focuses on evaluating the likelihood that given evidence would be observed if one theoretical explanation were true compared to others. ${ }^{77}$ This allows us to better adjudicate competing claims than other case-study techniques, especially in light of our uncommon foundations approach. Focusing on the probative value of evidence also allows us to dismiss some alternative explanations more quickly than others: "being equally tough on alternative explanations does not require going into equal depth ... on every one of them." 78 For more details, especially concerning data sources, see our online appendix.

Table 2 lays out the observable implications of our argument and how evidence should adjust our confidence in our theory when compared to the two rival accounts we evaluate here. In accord with process-tracing methodology, we lay out what we should most likely observe-or not-if our proposed mechanism is operational (but not rivals') or if rivals' mechanisms are operational (but not ours). Different potential observations - or lack of observations - should adjust our relative confidence in our theory relative to its rivals. Different observations - or lack of observations-can have different effects on our judgment about rival theories. Specifying levels of confidence facilitates transparency and also provides a marker about how observations (for instance, if Ming court records are ever rediscovered) would affect our judgment.

\section{Voyages of the Ming Treasure Fleets}

In $1405 \mathrm{CE}$, Zhu Di, the Yongle emperor of China's Ming dynasty, authorized the first of seven massive naval expeditions from China to the Indian Ocean in 1405. ${ }^{79}$ Other voyages took place in 1407-9, 1409-11, 1413-15, 1417-19, 1421-22, and

76. Bennett and Checkel 2014.

77. Humphreys and Jacobs 2015, 653; Zaks 2017.

78. Bennett and Checkel 2014, 23-24.

79. Wade 2008, 592. 
TABLE 2. Observable implications and evidentiary significance

\begin{tabular}{|c|c|c|c|c|c|}
\hline \multirow[b]{2}{*}{ Implications } & \multicolumn{3}{|c|}{$\begin{array}{l}\text { Conditions under which rival theories } \\
\text { would predict observation }\end{array}$} & \multirow[b]{2}{*}{ Evidentiary value if observed } & \multirow[b]{2}{*}{ Evidentiary value if not observed } \\
\hline & Our theory & $\begin{array}{l}\text { Economic } \\
\text { efficiency }\end{array}$ & $\begin{array}{l}\text { Security } \\
\text { concerns }\end{array}$ & & \\
\hline 1. Subject is a politically superordinate actor? & Required & Irrelevant & Irrelevant & $\begin{array}{l}\text { Very low for our theory; irrelevant for } \\
\text { rivals }\end{array}$ & $\begin{array}{l}\text { Dispositive against our theory; } \\
\text { irrelevant for rivals }\end{array}$ \\
\hline $\begin{array}{l}\text { 2. Subject faces demonstrable crisis of legitimacy } \\
\text { (e.g., fears that subordinates/potential subordi- } \\
\text { nates will reject its right to exercise leadership? }\end{array}$ & Required & Irrelevant & $\begin{array}{l}\text { Possible but } \\
\text { not required }\end{array}$ & $\begin{array}{l}\text { Very low for our theory; irrelevant for } \\
\text { economics; weakly favorable for } \\
\text { security }\end{array}$ & $\begin{array}{l}\text { Dispositive against our theory; } \\
\text { irrelevant for economics; very } \\
\text { low for security }\end{array}$ \\
\hline $\begin{array}{l}\text { 3. Subject responds by seeking to accrue symbolic } \\
\text { capital by diverting assets from other military or } \\
\text { economic uses? }\end{array}$ & Required & Unlikely & $\begin{array}{l}\text { Extremely } \\
\text { unlikely }\end{array}$ & $\begin{array}{l}\text { Moderately in favor of our theory; } \\
\text { damaging to economic arguments; } \\
\text { strongly damaging to security } \\
\text { arguments }\end{array}$ & $\begin{array}{l}\text { Dispositive against our theory; } \\
\text { weakly supportive to rivals }\end{array}$ \\
\hline 4. Project ends when legitimacy crisis has ceased? & $\begin{array}{l}\text { Likely but not } \\
\text { required }\end{array}$ & Irrelevant & Irrelevant & $\begin{array}{l}\text { Moderately in favor of our theory; } \\
\text { neither supportive nor damaging to } \\
\text { rivals }\end{array}$ & $\begin{array}{l}\text { Damaging, not quite dispositive } \\
\text { against, our theory; neither sup- } \\
\text { portive nor damaging to rivals }\end{array}$ \\
\hline $\begin{array}{l}\text { 5. Leaders expect that direct benefits (military or } \\
\text { economic) separate from symbolic capital justify } \\
\text { expenditures }\end{array}$ & $\begin{array}{l}\text { Extremely } \\
\text { unlikely }\end{array}$ & Required & Required & $\begin{array}{l}\text { Highly damaging against our theory, } \\
\text { supportive for rivals }\end{array}$ & $\begin{array}{l}\text { Highly damaging against rivals, } \\
\text { moderately favorable for our } \\
\text { theories }\end{array}$ \\
\hline
\end{tabular}


1431-33. They covered an increasing distance: the first expedition visited Southeast Asia, Indochina, and modern-day Kolkata and Sri Lanka; the sixth—the last under the Yongle emperor-visited as far as Aden and the East African coast. ${ }^{80}$ Most were commanded by the eunuch admiral Zheng He.

The Yongle emperor died in 1424. On the advice of scholar-elite officials, his son and successor Zhu Gaochi, the Hongxi emperor, canceled further voyages. The Hongxi emperor unexpectedly died in 1425 after less than a year on the throne. His son and successor, Zhu Zhanji-the Xuande emperor-commissioned a seventh expedition that sailed in 1433 and may have intended only to repatriate foreign ambassadors and personnel. But the Xuande emperor died in 1435, at roughly the same time as Zheng He. The new emperor, Zhu Qizhen (known both as the Zhengtong emperor, 1435-1449, and as the Tianshun emperor, 1457-1464), discontinued the voyages. Sources concur that no serious attempts to revive the treasure fleets followed the Zhengtong emperor's reign.

\section{Theoretical Applicability}

We expect that otherwise superordinate actors will divert substantial resources to maintain their position in a field where their dominance is challenged. The Yongle emperor faced such a crisis because he had succeeded to the throne illegitimately: following a massive civil war from 1399 to 1402 , he usurped the throne from his nephew, whom he (almost certainly) killed - "one of the most extraordinary cases of usurpation in the late imperial period." ${ }^{81} \mathrm{He}$ immediately confronted massive challenges. To quell external threats - especially from northern nomads ${ }^{82}$ - he employed a combination of diplomacy and warfare; to ward off an internal military challenge, he created a new military "nobility" loyal to him; to purge former regime loyalists, he executed hundreds of officials and "tens of thousands of innocent people"; and to further both policies, he removed the capital from Nanjing to the former Mongol capital, a northern city he renamed Beijing. ${ }^{83}$

His chief "national security" task, however, was legitimizing his rule. ${ }^{84}$ After mass executions failed to settle the issue ${ }^{85}$ he turned to an alternative strategy. Ming dynastic governance required the emperor to abide by an extensive, demanding set of norms drawn from tradition and invented by elites. ${ }^{86}$ Such norms were overseen by Confucian scholar-officials who staffed the bureaucracy. Western scholars later labeled one important set of practices the "tributary system": a set of rituals through which external rulers acknowledged the Chinese emperor as their superior in an

80. Needham 1971, 489-90. See also Dreyer 2007.

81. Cham 2007, 78.

82. Rossabi 1998.

83. On the scope of the purge, Cham 2007, 94. On the policy context, Cham 1988, 206-208.

84. Cham 1988, 184-201.

85. Ditmanson 2007, 110-58; Hucker 1998, 201-202.

86. See Hucker 1998. 
explicitly hierarchical system of international relations. The Ming court conducted relations with many powerful actors outside its direct ambit—including the polities whose successors would later become known as Korea and Japan-through such practices. ${ }^{87}$ The Hongwu emperor, the dynastic founder, placed special emphasis on the system. ${ }^{88}$ Demonstrations that the emperor commanded respect as the ruler from beyond the borders of the Chinese amounted to symbolic capital in the Ming political field.

The Yongle emperor expanded these practices to an unprecedented degree. The treasure fleets amounted to a bricolage of customs through which the Yongle emperor employed the resources of the imperial treasury to "prove" his legitimacy by seeking the validation of external "subjects." Crucially, these expeditions were not voyages of discovery. Chinese merchants and others described the Arab world and Eastern Africa as early as $860 \mathrm{CE}$, and Ming-era traders already enjoyed extensive commercial contacts with many of the ports that the fleets visited. ${ }^{89}$ The treasurefleet expeditions "were essentially an urbane but systematic tour of inspection of the known world." 90 Their mission was to convince local potentates to enroll in the tributary system. In most instances, the fleets' trade goods proved sufficient to buy such loyalty. If not, "the Treasure-ships were intended not only to dazzle foreign peoples with their wealth and majesty but to overawe potential opposition with their might and firepower." 91 The fleet sometimes employed more coercive means. On each of the early voyages, the fleet—and its troops-suppressed pirates and other outlaws. It also deployed force against local governments who attacked the fleet. ${ }^{92}$

The fleets succeeded at expanding the emperor-centric world order, enrolling as many as forty-eight states in the system (many for the first time) ${ }^{93}$ When the expeditions returned to the Ming court, they brought back not only valuable goods and ambassadors but even foreign rulers-visible tokens of the extension of Ming prestige throughout the known world. ${ }^{94}$ They also carried exotic treasures like giraffes from Africa - which the court proclaimed to be qilin, mythological beings said to appear during the rule of an illustrious ruler. ${ }^{95}$

The observations thus fit the pattern we would expect given our predictions in Table 2. The case meets the criteria required in implications 1,2 , and 3 . Similarly, there seems to be strong evidence that implication 4 , about the termination of the voyage, also fits the pattern we predict. In particular, the fact that the voyages largely stopped with the demise of the Yongle emperor suggests that the legitimacy crisis was tied to his reign (as one would expect given his usurper status - his successors came to the throne legitimately).

87. Kang 2010; Zhang 2015.

88. Finlay 2008.

89. Needham 1971, 494.

90. Ibid., 529.

91. Finlay 1991, 8. Wang suggests that the court ran a loss on these exchanges in order to bribe foreign officials to join the tributary system. 1998, 320

92. Finlay 1991, 12; Wade 2008, 49-51; Wang 2012, 144-46.

93. Finlay 1991, 10.

94. Wade 2008, 597.

95. Church 2004; Wyatt 2008. 


\section{Alternative Explanations}

Economic Efficiency. If economic arguments based on trade explained the voyages, then (as implication 5 in Table 2 summarizes) the scale of the outlay needed for the vessels would have required expectations of a commensurate return on investment. The scale of the fleets undermines this explanation. The 1405 voyage alone included seven ambassadors, ten deputy ambassadors, a few dozen supervisors, 800 sailors, and 26,000 soldiers and their officers. ${ }^{96}$

A fleet constructed for economic returns should have minimized costs; one constructed for symbolic purposes would have overinvested in displays of status. Consider the mammoth investments involved: from felling entire forests to employing "hundreds of households of carpenters, smiths, sailmakers, ropemakers, caulkers, carters and haulers, even timekeepers." 97 Such investments would be hard to justify even for luxury goods. It remains unclear if the goods acquired on the voyage even reached Chinese marketplaces or if they remained in the court. ${ }^{98}$

A secondary clue comes from the emphasis on political relationships as a goal of the fleets; economic motives cannot explain why the voyages so closely tracked the tributary system. Moreover, it strains credibility that the voyages would have become (or have been seen to become) uneconomical just as the Yongle emperor died (implication 4). We find economic explanations unsatisfactory; the most valuable "good" purchased by the fleets was symbolic obeisance (as consonant with implication 3) and that the fact pattern predicted does not fit an economic explanation.

Military Security. The Ming faced or initiated security challenges in Vietnam and in Mongolia, both near their core areas. The vast sums the court directed toward the expeditions had no bearing on these military campaigns, nor were they directed against an "overthe-horizon" threat. They also didn't yield alliances of much tangible benefit. Given the expenditures necessary to sustain these expeditions, the treasure fleets entailed significant opportunity costs for Ming military security. As Hoffman asks, "why pour money into the fleets when the real danger came from nomads instead?"'99 Consequently, we find that this explanation would contradict the observed fact pattern, and, according to implication 5, we argue for summarily dismissing the security explanation.

\section{Project Apollo}

At the dawn of the Cold War, Washington and its allies recognized the existence of a US-led order comprising (at least) the advanced industrialized democracies, most of

96. Finlay 1991, 12.

97. Landes 1999, 95-96.

98. Cham 1988, 236.

99. Hoffman 2015, 70 . 
Latin America, and much of noncommunist Asia. ${ }^{100}$ This fits with implication 1: the United States (and its president) were politically superordinate actors. As implication 2 requires, the Cold War created an ongoing possibility of demonstrable crises of legitimacy. US and other Western leaders saw the Soviet Union as both a material challenger and an ideological rival with the capability to attract the political support of both the "new nations" (as the then-current phrase described the decolonizing world) and, potentially, their own citizens and states. ${ }^{101}$ It may seem fantastic today, more than twenty-five years after the collapse of the USSR, but Soviet communism once appeared not only as a viable alternative to liberal capitalism but also potentially a superior one. Consequently, from the 1950s onward, Washington and Moscow competed to retain existing allies and attract new ones in Latin America and decolonizing regions of Africa and Asia. There was significant uncertainty about which side the "third world" would join. ${ }^{102}$ Many leaders—and ordinary people across the globe-believed the United States could lose the Cold War by failing to concretely and continuously make good on the promise of its ideological wagers. ${ }^{103}$

Science and technology has long roots as a field of competition, but it emerged as a critical field —and specifically in terms of space-almost literally overnight. ${ }^{104}$ On 4 October 1957, the Soviet Union launched Sputnik, the first artificial satellite. The scale of Western and nonaligned shock at Sputnik surprised the Soviet leadership. The Kremlin quickly moved to capitalize on its success. Success in space became constructed as a contest over whether Soviet communism or democratic capitalism was superior for humankind. ${ }^{105}$ Moscow disregarded the Soviet space establishment's scientific priorities to better promote satellites, and later human space missions, as advertisements for Communism. ${ }^{106}$ American officials viewed the challenge as a test of national competence and prestige. ${ }^{107}$ In keeping with the construction of the field of competition, accounting for progress in the space race quickly became routinized. A January 1960 CIA assessment, for instance, included a table comparing US and USSR accomplishments in fields as specific as "Ionosphere" and "Geodesy" (Figure 1)—a formal statement setting out how scientific capital was exchanged into prestige. ${ }^{108}$

100. Particularly after the Suez crisis.

101. For instance, Saunders 2013 and Von Eschen 2009.

102. For a survey, Gaddis 2006, 119-55, and Westad 2007, 92.

103. As we elaborate, the symbolic stakes of the Apollo program go beyond those scholars identifying national projects as status symbols in general, and space projects in particular. Steinberg 1987.

104. See online appendix.

105. Early 2014, 56; Fursenko and Naftali 2007, 138-67; McDougall 1985; Sheehan 2007, 25-32, $40-42$.

106. Fursenko and Naftali 2007, 149-52; Sheehan 2007, 28-29.

107. US Information Agency, Office of Research and Analysis, "Impact of US and Soviet Space Programs on World Opinion," 7 July 1959, US President's Committee on Information Activities Abroad (Sprague Committee) Records, 1959-1961, Box 6, A83-10, Dwight D. Eisenhower Library, Abilene, Kansas.

108. "A Comparison of US and USSR Capabilities in Space," 1 January 1960, CIARDP80B01676R004000110002-6. On the importance of the construction of indexes to the generation of fields, see Gilady 2006, 78 and Gilady 2017, 46-50. 
Comparison of U.S。 and USSR in Varlous Fields of Space Science

\begin{tabular}{|c|c|c|}
\hline & Field & Status \\
\hline Unclassified & Geodesy & $U_{\text {. }} S_{\text {o }}$ ahead \\
\hline & High Energy Particle Radiations & U.S. ahead \\
\hline & Solar and Stellar Radiations & U.S, ahead \\
\hline & Upper Atmosphere & U.S. slightly ahead \\
\hline & Aurora & U.S。 slightly ahead \\
\hline & Magnetic Fields & Comparable \\
\hline & Meteors & Comparable \\
\hline & Meteorology & Comparable \\
\hline & Ionosphere & USSR slightly ahead \\
\hline & Lunar Measurements & USSR ahead \\
\hline & Biosciences & USSR ahead \\
\hline
\end{tabular}

FIGURE 1. Table reproduced from CIA report assessing US and USSR accomplishments in space, 1 January 1960

The most important impact of this field of rivalry in space was on the competition for the hearts and minds of the nonaligned world. "The flight of Sputnik ... impressed many ordinary Latin Americans; some recalled it as the first time they ever heard of the Soviet Union."109 A July 1959 United States Information Agency (USIA) assessment of the "Impact of US and Soviet Space Programs on World Opinions" found particular shifts about popular views toward the US-Soviet balance in Latin America, where it estimated that "the two nations are about equal;" in Africa, where both sides were also regarded as equal but where that "assessment ... represent[ed] a very significant revision of views concerning the nature of Soviet society;" and in India, where "Soviet dramatic successes appear to have decisively implanted the opinion that the Soviet Union is now the world scientific leader." 110 The December 1960s "Sprague Committee" report on reorganizing US efforts to disseminate information internationally took for granted that science and technologyespecially space-would prove to be an enduring part of this Cold War competition

109. Rupprecht 2015,42

110. US Information Agency, Office of Research and Analysis, "Impact of US and Soviet Space Programs on World Opinion." 
for global influence (Figure 2), remarking that "throughout the world the status of the nation's science is increasingly taken as a measure of its power and dynamism." 111

\section{Scientific and Technological Programs}

A startling new development in the period since the Jackson Committee report has been the increasing impact of scientific and technological achievement upon world opinion. Without question the launching of the first Sputnik gave the Soviet Union a psychological triumph which has profoundly affected its image as a technically advanced nation and as a great military power. Its feat in one branch of technology has been systematically exploited-and with considerable success-as evidence of the dynamism of the entire Soviet system.

The United States has had, and continues to have, over-all superiority in science and technology. Nevertheless, since the launching of Sputnik I there has been considerable evidence that the average man in most countries believes that Soviet capability continues to grow relative to that of the United States, and that the Soviet Union leads in certain important aspects of space technology. Short of some now unforeseeable and revolutionary scientific breakthrough, it will be extremely difficult to re-establish the degree of American technological prestige and pre-eminence relative to that of the USSR which existed prior to October 1957.

The Committee feels that, since throughout the world the status of the nation's science is increasingly taken as a measure of its power and dynamism, two things are indispensable psychologically: (1) that the U. S. maintain a continuing stream of scientific and technological achievements; and (2) that these achievements be more effectively communicated to the world than has been the case in the past.

The Committee feels that, despite the improvements which have been made, there is still an inadequate awareness of the psychological importance of our scientific activities in the administration of these programs and that arrangements for publicizing and dramatizing to the world our achievements are inadequate.

FIGURE 2. Selection from the Sprague Committee Report (p. 36 of original).

\section{Gagarin's Orbit and Kennedy's Crisis of Legitimacy}

By Kennedy's inauguration, leaders, elite, and mass audiences around the globe-in the Soviet Union and the United States, their allies, and the nonaligned worldviewed space activities as competitive, meaningful, and linked to assessments of not only each camp's military abilities but also the attractiveness of their systems. The furor over Sputnik had largely subsided when Kennedy succeeded Eisenhower

111. Conclusions and Recommendations of the President's Committee on Information Activities Abroad, December 1960, CIA-RDP86B00269R001000010003-7 (Declassified 22 April 2008). 
in January 1961. Kennedy's generally bellicose inaugural address even singled out space and science as an area of potential East-West cooperation. ${ }^{112}$ Yet space reemerged as a competitive arena on 12 April 1961, when Soviet cosmonaut Yuri Gagarin completed an Earth orbit on Vostok $I$ to become the first human in space. ${ }^{113}$ This Soviet triumph was "a worse blow to US prestige than the Sputnik launch ... since by 1961 the American people and US allies abroad were aware that the US had been engaged in a competition to launch an astronaut before the Soviet Union."114

On 21 April (two days after the withdrawal of CIA-backed guerrilla forces from Cuba's Bay of Pigs), a USIA assessment of Gagarin's orbit on global media opinion concluded that "the Soviet feat is generally held to have increased and consolidated the Soviet lead in space, and to increase Soviet military, political, and propaganda leverage." 115 Survey evidence later confirmed qualitative claims. In October 1961, USIA reported on polls of Western European public confidence in the United States. The document was sent only to the White House and two other agencies "because of the obvious political combustibility of the survey."116 It found Europeans rated the Soviets as besting the Americans' "lead in space developments as follows: Britain 78\% [Soviet lead] to $7 \%$ [American lead]; France $80 \%$ to $2 \%$; Italy $62 \%$ to $11 \%$; and West Germany $67 \%$ to $12 \%$."

The Kennedy administration believed that the United States, as "leader of the Free World," needed to constantly demonstrate its attractiveness and fitness to the nonaligned countries and its allies. Such thinking fit with a December 1960 CIA National Intelligence estimate that argued that Soviet leaders regarded the fact that "a Communist rocket which first ventured into space symbolizes for them that they are marching in the vanguard of history." 117 Consequently, as Westad writes, "for Kennedy and his advisers, the key to what America could do to help avoid breakdown in the Third World was held by its technological success." 118 Nor were such concerns limited to the Third World. That USIA paid such careful attention to public opinion polling on space is consistent with the Kennedy administration's worries that even countries such as West Germany and Italy might become neutral as a result of declining confidence in the West spurring votes for left-wing parties. ${ }^{119}$

112. John F. Kennedy: "Inaugural Address,” 20 January 1961, The American Presidency Project, <http:// www.presidency.ucsb.edu/ws/?pid=8032>.

113. McDougall 1985, 317-24.

114. Sheehan 2007, 48.

115. US Information Agency Office of Research and Analysis, "Initial World Reaction to Soviet 'Man in Space,"” 21 April 1961, JFK Presidential Library.

116. Donald M. Wilson to President Kennedy, 19 October 1961, <https://www.jfklibrary.org/AssetViewer/Archives/JFKPOF-091-002.aspx>. Besides the White House, USIA sent the report to "the Secretary of State and CIA (who paid half of the bill)."

117. CIA, National Intelligence Estimate NIE 11-4-60, "Main Trends in Soviet Capabilities and Policies, 1960-1965," FRUS 1961-1963, Volume V, "Soviet Union,” Document 1.

118. Westad 2007, 35.

119. See, for instance, Kennedy's remarks to the Italian government in 1963: "With the large Communist vote in Italy, the question of the future in France after De Gaulle, and the uncertain situation in Spain, Portugal, and Greece, there were many points of instability in the West." FRUS 1961-1963, Volume 13, 
We therefore conclude that policymakers understood Gagarin's flight as sparking a crisis on the terms of American legitimacy-evidence consistent with implication 2. The question facing the White House in late April and early May 1961 was thus how to respond. Both Kennedy and his vice president, Lyndon Johnson, had been starkly critical of Eisenhower's seemingly blasé response to Sputnik and believed that his reluctance to take a stronger line had cost him at home and abroad. ${ }^{120}$ Thus, as in implication 3, Kennedy and his administration chose to accrue symbolic capital by investing massively in a display of competence. Setting the goal of a lunar landing stemmed not from some supposed romantic yearning for a final frontier, but rather a calculated search for a benchmark where US disadvantages vis-à-vis the Soviet Union—notably, its lack of a reliable heavy-lifting rocket—would be counterbalanced by its superior industrial and organizational potential. ${ }^{121}$ But Kennedy also wanted to pursue the minimum goal that would convincingly demonstrate US superiority. He pushed his advisers to investigate alternative national goals—putting a laboratory in space, a manned circumnavigation of the moon, landing a robotic probe on the lunar surface, or (his last choice) "a rocket to go to the moon and back with a man." 122 NASA advised that the most ambitious option, a manned lunar mission, provided the only sure chance of beating the Soviets. ${ }^{123}$

Kennedy's decision to proceed with Apollo to demonstrate that US capabilities matched US pretensions in global hierarchies provides important evidence consistent with implications 3 and 5. The scale of Project Apollo's drain on US resources may seem surprising. Apollo ranks with the most expensive public works and defense projects carried out by the US government. The World War II-era Manhattan Project, which developed the first atomic weapons, cost approximately $\$ 22$ billion in 2008 dollars; by contrast, Apollo cost $\$ 98$ billion. ${ }^{124}$ At its peak, the Manhattan Project claimed 1 percent of annual federal spending; Apollo peaked at 2.2 percent of the

\footnotetext{
Western Europe and Canada, Document 318 ("Memorandum of Conversation," 1 July 1963, involving the Italian government and President Kennedy). In a discussion about Italy's internal political situation with the Joint Chiefs of Staff, US Ambassador to Italy Frederick Reinhardt not only carefully reviewed the state of play regarding coalition politics but also noted that "the Italians have an increasing awareness of space activities and they are very happy with our success."

120. See, for instance, "Briefing Paper on Space," Papers of John F. Kennedy, Pre-Presidential Papers, Presidential Campaign Files, 1960. Issues. Position and Briefing Papers, 1960. Briefing Papers: Social Security, Space, Tax, Unemployment, Veterans' Affairs, Water Pollution. <https://www.jfklibrary.org/ Asset-Viewer/Archives/JFKCAMP1960-0993-020.aspx>.

121. Jerome Wiesner to Kennedy, 20 February 1961, in Foreign Relations of the United States [FRUS] 1961-63, Vol. 25, Document 386.

122. Logsdon 2010, 80.

123. Dryden Notes, 22 April 1961, in FRUS 1961-1963, Vol. 25, Document 362. These closely track conclusions about Soviet capabilities reached by an Eisenhower-era National Security Council report years before. FRUS 1958-1960, Vol. 2, Document 442, Annex A.

124. For simplicity's sake, we refer to the entire manned space effort during the 1960s as part of Project Apollo, although technically earlier suborbital and orbital flights under Project Mercury and Project Gemini were separate.
} 
federal budget. ${ }^{125}$ It was unusual for the fiscally restrained Kennedy to endorse such a costly plan, but he never hid the scale of the commitment: a budget official later recounted that "there was never a major decision like this made with the same degree of eyes-open, knowing-what-you're-getting-in-for" character. ${ }^{126}$ In his 25 May 1961 speech, he told Congress that "No single space project in this period will be more impressive to mankind or more important for the long-range exploration of space, and none will be so difficult or expensive to accomplish."127

What was Kennedy paying for? Symbolic capital-defined as demonstrating that the United States, despite its poor showing in the space-race spectacles, was, in fact, dominant in science and technology. Internal Kennedy administration budget memoranda grouped NASA budgets with military and diplomatic expenditures, not with civilian agencies. In December 1961, Kennedy's budget bureau projected that by 1963 NASA would incur obligations of $\$ 3.78$ billion, compared to foreign economic aid ( $\$ 3.19$ billion), foreign military aid ( $\$ 1.5$ billion), and the entire State Department ( $\$ 0.35$ billion). NASA was thus the largest line item in this category except for the military functions of the Department of Defense. ${ }^{128}$ Such evidence reaffirms our interpretation that policymakers envisioned Apollo's international implications as warranting a nearly wartime mobilization of resources; NASA's classification among other military and diplomatic line items reaffirms the power-political nature of Apollo.

Overwhelming evidence corroborates our interpretation. ${ }^{129}$ For instance, in a joint memorandum two weeks before Kennedy's public announcement of Apollo, NASA administrator James Webb and Defense Secretary Robert McNamara argued for increased spending on manned space exploration despite its lack of military payoff: "major successes, such as orbiting a man as the Soviets have just done, lend national prestige even though the scientific, commercial or military value of the undertaking may by ordinary standards be marginal or economically unjustified." 130 The Webb-McNamara memorandum - crafted to support and elaborate a decision to respond that had already been made-assessed that "projects in space may be undertaken for any one of four principal reasons ... gaining scientific knowledge ... commercial or chiefly civilian value ... potential military value ... [or]

125. Stine 2009,6 . These numbers are conservative. Launius $(2012,168)$ describes NASA as claiming almost 4 percent of all federal expenditures during Apollo's peak years, while Logsdon estimates the total Apollo cost at $\$ 151$ billion in 2010 dollars. 2010, 2-3.

126. Logsdon 2010, 118.

127. John F. Kennedy, "Special Message to the Congress on Urgent National Needs," 25 May 1961, The American Presidency Project, <http://www.presidency.ucsb.edu/ws/?pid=8151>.

128. "Expenditure Outlook," 26 December 1961, David E. Bell Files, Box 14, File "Executive Branch Memoranda," John F. Kennedy Presidential Library.

129. Logsdon 2010, 12.

130. James E. Webb and Robert McNamara, "Recommendations for Our National Space Program: Changes, Policies, Goals," 8 May 1961, online reproduction of files from John F. Kennedy Library, $<$ https://research.archives.gov/id/193859>. 
for reasons of national prestige. The US is not behind in the first three categories ... The Soviets lead in space spectaculars which bestow great prestige." ${ }^{131}$ Webb and McNamara concluded:

This nation needs to make a positive decision to pursue space projects aimed at enhancing national prestige. Our attainments are a major element in the international competition between the Soviet system and our own. The non-military, non-commercial, non-scientific but "civilian" projects such as lunar and planetary exploration are, in this sense, part of the battle along the fluid front of the cold war ... It is vital to establish specific missions aimed mainly at national prestige.

Despite the romantic language of his public speeches about space, in private Kennedy continually reinforced the message that considerations of international prestige, not the intrinsic value of space exploration or space science, justified Apollo's expense. Kennedy put this forcefully in a tape-recorded November 1962 meeting with NASA Administrator James Webb and other officials. ${ }^{132}$

KENNEDY:

WEBB:

KENNEDY:

MULTIPLE SOURCES: KENNEDY:
Everything we do ought really to be tied to getting on the Moon ahead of the Russians.

Why can't it be tied to pre-eminence in space, which are your own ...

Because, by God, we keep-we've been telling everybody we're pre-eminent in space for five years and nobody believes it because they have the booster and the satellite. We know all about the number of satellites we put up, two or three times the number of the Soviet Union ... we're ahead scientifically. It's like that instrument you got up at Stanford which is costing us a hundred and twenty-five million dollars and everybody tells me we're the number one in the world. And what is it? I can't think what it is.

The linear accelerator.

I'm sorry, that's wonderful, but nobody knows anything about it! ... The policy ought to be that this is the top-priority program of the Agency, and one of the two things, except for defense, the top priority of the United States government. I think that that is the position we ought to take. Now, this may not change anything about that 
schedule, but at least we ought to be clear, otherwise we shouldn't be spending this kind of money because I'm not that interested in space. I think it's good; I think we ought to know about it; we're ready to spend reasonable amounts of money. But we're talking about these fantastic expenditures which wreck our budget and all these other domestic programs and the only justification for it, in my opinion, to do it in this time or fashion, is because we hope to beat them and demonstrate that starting behind, as we did by a couple years, by God, we passed them. ${ }^{133}$

Perhaps the best evidence of Kennedy's motivations comes from an earlier chastising of Webb's enthusiasm for the moon shot as a scientific endeavor: "But this is important for political reasons, international political reasons. This is, whether we like it or not, in a sense a race." Such remarks both demonstrate evidence consistent with implications 1, 2, and 3, and inconsistent with other explanations' predictions about what we should observe.

Further evidence for our interpretation comes from how Apollo ended. The original purpose of the Apollo project fit uneasily into changing relations between the United States and the USSR by the end of the decade. True, the US government showed off the lunar landings. President Richard Nixon greeted the Apollo 11 astronauts on board the USS Hornet after their splashdown in the Pacific Ocean, the centerpiece of his tour of US allies; ${ }^{134}$ the Apollo 11 astronauts toured twenty-four countries on the GIANTSTEP-Apollo 11 Presidential Goodwill Tour; ${ }^{135}$ and the Nixon administration sent lunar samples to 135 countries as tokens of US friendship. ${ }^{136}$ As many as 41 million people attended USIA-organized expositions of moon rocks around the world. ${ }^{137}$ The diplomatic uses of the Apollo missions even extended to include only two Communist leaders' voices on a disc left on the moon's surface: the American-friendly Yugoslavia's Marshal Tito and Romania's Nicolae Ceausescu. ${ }^{138}$

133. Transcript of presidential meeting in the Cabinet Room of the White House on Supplemental Appropriations for NASA, 21 November 1962, <http:/history.nasa.gov/JFK-Webbconv/pages/transcript.pdf>.

134. Heppenheimer 1999. Available at NASA History Office, <http://history.nasa.gov/SP-4221/ch9. htm>.

135. Priscilla Linn, "The Journey After 'One Giant Leap For Mankind'," Dipnote: US Department of State Official Blog, <http://2007-2017-blogs.state.gov/stories/2009/07/20/journey-after-one-giant-leapmankind.html>.

136. Kloc 2012.

137. Muir-Harmony 2014.

138. Vucetic 2011. 
These were not quite the victory laps that one might have expected given the competitive atmosphere in which the Apollo project had begun. By the end of the 1960s, "public diplomats' approach to space programming had shifted notably. Instead, the emphasis of programming portrayed space exploration as a global accomplishment." 139 It is not accidental that Neil Armstrong's words upon setting foot on the lunar surface were to stress that this was not an American accomplishment but a giant leap "for mankind."

Apollo's success, then, was ironic: even though the project met its goal, the world had changed around it, making that triumph worth much less than its authors had intended. ${ }^{140}$ Neither military-security nor economic analyses explain this decision to stop; it only makes sense in the context of a race that had been won-and which had, by the time the Americans won it, already lost its luster. As implication 7 suggests, this timing is more consonant with our preferred explanation than with rivals'.

\section{Assessing Competing Explanations}

How do rival explanations track with observed evidence? They do not perform well.

Military Security. There is some supportive evidence for the hypothesis that military concerns triggered spending on Apollo. For instance, the April 1961 USIA survey of world public opinion after Gagarin's orbit found that there was a "strong feeling that the Soviet feat has military implications and in some way enlarges Soviet military capabilities." Yet this evidence pales before other data suggesting that considerations of "military implications"-beyond audience perceptions of a link between space prowess and military capabilities-do not appear to have weighed on senior policymakers or President Kennedy.

Kennedy's advisers consistently argued that the moon project was separate from security needs. The Webb-McNamara memorandum of May 1961 echoed Wiesner's January 1961 transition memorandum on this point: although "it is generally assumed by the American citizen that our vast expenditures of money and technical talent are primarily designed to meet the overriding needs of our military security," missiles were "slowly being delegated to the category of routine management." Wiesner (and, later, Webb and McNamara) argued the most important factor in the national space effort was "the factor of national prestige ... During the next few years, the prestige of the United States will in part be determined by the leadership we demonstrate in space activities." 141

139. Muir-Harmony 2014, 36.

140. Although the progress of the project itself served these goals throughout the $1960 \mathrm{~s}$. We do not mean to suggest that the symbolic capital acquired—and conspicuously displayed—from Apollo turned out to be worthless for Kennedy's original purposes.

141. Wiesner 1961, 1. 
Nor was there the promise of substantial spillovers from moon-shot technology. The 1950s space race involved dual-use technologies, such as developing "missiles able to deliver nuclear weapons and satellites capable of securely performing reconnaissance missions." ${ }^{142}$ But US policymakers realized early that Apollo required boosters far more powerful than needed for any plausible military purpose. ${ }^{143}$ Even Soviet leader Nikita Khrushchev understood in 1962 that "space rockets require more powerful engines, since by this $[$ sic $]$ means they carry greater payloads and attain a higher altitude, while military rockets in general do not require such powerful engines-engines already in existence can carry warheads of great destructive force and assure their arrival at any point on the globe."144

In the early 1960s, US intercontinental ballistic missiles (ICBMs) switched to solid propellants, while NASA used liquid propellants, a distinction that limited civilianmilitary technology transfer. ${ }^{145}$ Given this evidence, there is little reason to think that a drive for military superiority, per se, played a role in the Apollo project, nor that direct military interests drove the project (see implications 3 and 5).

Economics. Although NASA press officers valiantly tried to justify Apollo as producing large spillover effects, specific claims about its economic benefits tend to conflate the lunar program with other uses of space, such as earth observation and telecommunications. Otherwise, they rest on nebulous claims of long-term benefits. ${ }^{146}$ Such arguments also tend to ignore or downplay the opportunity cost of human space exploration compared to alternative modes of exploration. Although the first manned circumlunar voyage occurred in 1968, robotic missions to the Moon proved feasible as early as the Soviet Luna missions in 1959. Unmanned science could have produced many, if not all, of the same technological spillovers claimed for manned missions. Van Dyke writes that "if there were no reasons for the lunar program other than the prospect that it would produce economic ... benefits, it is safe to say that very few would consider it justifiable." ${ }^{147}$ Little evidence supports the contention that economic motives took priority.

Both of these functionalist explanations would be hard-pressed to explain why the moon missions stopped when they did, except through some process of learning that

142. Sheehan 2007, 8-9.

143. For instance, Summary Minutes of the Meeting of the National Aeronautics and Space Council, FRUS Vol. 25, Document 367.

144. Khrushchev to Kennedy, 20 March 1962, English translation, JFK Presidential Library National Security Files, Box 308, Folder "US-USSR Space Cooperation 1961-1963."

145. Senior Airman Reggie Manning, "Air Force History of ICBM Development, Safeguarding America," $<$ http://www.afgsc.af.mil/News/Features/Display/Article/455710/air-force-history-of-icbm-developmentsafeguarding-america/> and "Table of US ICBM Forces," NRDC, <http://www.nrdc.org/nuclear/nudb/ datab3.asp>.

146. See, for instance, the contributions of NASA officials and others to a symposium on the Freakonomics blog. "Is Space Exploration Worth the Cost? A Freakonomics Quorum" retrieved from $<$ http://freakonomics.com/2008/01/11/is-space-exploration-worth-the-cost-a-freakonomics-quorum/>.

147. Van Dyke 1964, 118. 
the security or economic returns were lower than expected; we have encountered no such evidence of dashed expectations.

\section{Conclusion}

Today, Project Apollo and the treasure fleets conjure images of national greatness squandered by subsequent generations of lesser, narrow-minded politicians. Unsurprisingly, American presidents seeking to discover a legacy have recurrently toyed with the idea of sending astronauts to the moon or even to Mars. Despite the seemingly large rewards of doing so, no such project has come to fruition. The putative grandeur of Apollo and the Ming fleets sits uneasily with the fact that they were, in military and economic terms, massive wastes of resources that diverted labor and treasure into, in those terms, unproductive ventures. Despite their current rhetorical status, it was not a desire for altruistic "greatness" but a need for self-interested symbolic domination that justified such extravagances. In the absence of such a challenge, the game is not worth the candle.

We wager that understanding the processes that could transform legitimacy crises into such performances can, in turn, illuminate other recurrent patterns in world politics. Despite their significant differences - their uncommon foundations - the cases display similar mechanisms and processes associated with the politics of hierarchy and maintaining political dominance, whether in terms of dynastic politics or science-and-technology competition. In finding common mechanisms and processes across the layered hierarchies at stake in Ming China (core, empire, and tributary system) and Cold War America (core, asymmetric alliances, and zones of competition for clients and allies), we show the payoffs to a key wager of hierarchy-centric scholarship: that international relations and domestic politics blur together when it comes to the leverage provided by explanatory theory.

This juxtaposition also allows us to engage with Acharya's important call for a "global" approach to the study of international politics by comparing the kinds of systems that long constituted international-relations scholars' bread and butter, like the Cold War, and non-Western systems that have received less attention, like Ming China. This comparison is particularly salient given widespread interest in interrogating early modern Chinese international relations, including attempts to compare it to postwar American hegemony. ${ }^{148}$

We also seek to advance more pluralist ways of studying power politics. Scholars should combine sensibilities from social-constructionist and strategic approaches to understand power politics. Such dynamics extend beyond straightforward economic and military competition; they may employ instruments outside the typical 
repertoire. ${ }^{149}$ Both cases provide examples of high-stakes power politics. But the immediate objects - the capital —at stake took the form of tokens and performances of, on the one hand, obeisance from distant rulers and, on the other, science-and-technical prowess in space. The Yongle's and the Kennedy courts' policy choices involved incontestably strategic and instrumental dimensions, yet played out in socially constructed fields that cannot be explained in purely "objective" terms.

Finally, the field-theoretic approach we offer provides a means of cutting into the dynamics of hegemony at the level of individual diplomats, in institutional sites, and between states. While we focused on the last, fields specific to micro-level settings coexist with more macro-level ones, and they should influence one another. ${ }^{150}$ This is the direction that advocates of hierarchy-centric scholarship point to: seeing world politics as composed of complex patterns of super- and subordination that incentivize "compliant and resistant behavior," generate "positional and role-based behaviors," and "produce distinctive political spaces."151 A hierarchy-centered account of world politics will also have to offer accounts of what kinds of competition will be generated under hierarchy, how contests for domination and acceptance of subordination will proceed, and why the forms of such hierarchies will change over time. By illuminating how legitimacy challenges can produce state actions that mobilize resources on a wartime scale, we seek to show that the stakes of these debates matter for more than abstract concerns: they describe processes at the core of political life.

\section{Supplementary Material}

Supplementary Material for this article is available at <https://doi.org/10.1017/ S0020818318000139>.

\section{References}

Acharya, Amitav. 2014. Global International Relations (IR) and Regional Worlds. International Studies Quarterly 58 (4):647-59.

Adler-Nissen, Rebecca. 2008. The Diplomacy of Opting Out: A Bourdieudian Approach to National Integration Strategies. Journal of Common Market Studies 46 (3):663-84.

- 2014. Stigma Management in International Relations: Transgressive Identities, Norms, and Order in International Society. International Organization 68 (1):143-76.

Adler-Nissen, Rebecca, and Vincent Pouliot. 2014. Power in Practice: Negotiating the International Intervention in Libya. European Journal of International Relations 20 (4):889-911.

149. Goddard and Nexon 2016. See also Avant and Westerwinter 2016; Barkin 2003; Bially Mattern 2004; Goddard 2008/2009; Guzzini 1993; and Hurd 2005.

150. Go and Krause 2016. See also Adler-Nissen and Pouliot 2014; Krieger, Souma, and Nexon 2016; and Pouliot 2011.

151. Bially Mattern and Zarakol 2016, 634. 
Agathangelou, Anna M., and Lily H.M. Ling. 2009. Transforming World Politics: From Empire to Multiple Worlds. New York: Routledge.

Arnoldi, Jakob. 2007. Universities and the Public Recognition of Expertise. Minerva 45 (1):49-61.

Avant, Deborah, and Oliver Westerwinter, eds. 2016. The New Power Politics: Networks and Transnational Security Governance. New York: Oxford.

Barder, Alexander D. 2016. International Hierarchy. The International Studies Encyclopedia, Cambridge, MA: Blackwell.

Barfield, Thomas J. 1989. The Perilous Frontier: Nomadic Empires and China, 221 BC to AD 1757. Cambridge, MA: Blackwell.

Barkawi, Tarak, and Mark Laffey. 1999. The Imperial Peace: Democracy, Force and Globalization. European Journal of International Relations 5 (4):403-34.

Barkin, J. Samuel. 2003. Realist Constructivism. International Studies Review 5 (3):325-42.

Barnhart, Joslyn. 2016. Status Competition and Territorial Aggression: Evidence from the Scramble for Africa. Security Studies 25 (3):385-419.

Baron, Ilan Zvi. 2014. The Continuing Failure of International Relations and the Challenges of Disiplinary Boundaries. Millennium 43 (1):224-44.

Barr, Michael. 2012. How Chinese Identity Politics Shapes Its Depictions of Europe. Review of European Studies 4 (3):45-53.

Bennett, Andrew, and Jeffrey T. Checkel. 2014. Process Tracing: From Philosophical Roots to Best Practices. In Process Tracing: From Metaphor to Analytic Tool, edited by Andrew Bennett and Jeffrey T. Checkel, 3-38. Cambridge, UK: Cambridge University Press.

Berling, Trine Villumsen. 2012. Bourdieu, International Relations, and International Security. Theory and Society 41 (5):451-78.

Bially Mattern, Janice. 2004. Ordering International Politics; Identity, Crisis and Representational Force. New York: Routledge.

Bially Mattern, Janice, and Ayşe Zarakol. 2016. Hierarchies in World Politics. International Organization 70 (3):623-54.

Bourdieu, Pierre. 1986. The Forms of Capital. In Handbook for Theory and Research for the Sociology of Education, edited by John G. Richardson, 241-58. New York: Greenwood Press.

Bourdieu, Pierre, and Loï J. Wacquant 1992. An Invitation to Reflexive Sociology. Chicago: University of Chicago Press.

Bull, Hedley 1977. The Anarchical Society: A Study of Order in World Politics. London: Macmillan.

Bukovansky, Mlada. 2002. Legitimacy and Power Politics: The American and French Revolutions in International Political Culture. Princeton, NJ: Princeton University Press.

Butt, Ahsan. 2013. Anarchy and Hierarchy in International Relations: Examining South America's WarProne Decade, 1932-41. International Organization 67 (3):575-607.

Burnham, Peter. 1991. Neo-Gramscian Hegemony and the International Order. Capital and Class 15 (3): 73-92.

Buzan, Barry. 1993. From International System to International Society: Structural Realism and Regime Theory Meet the English School. International Organization 47 (3):327-52.

Cham, Hok-Lam. 1988. The Chien-wen, Yung-lo, Hung-hsi, and Hsuan-te Reigns, 1399-1435. In the Cambridge History of China, Volume 7, The Ming Dynasty, 1368-1644, Part I, edited by F.W. Mote and D. Twitchett, 182-304. Cambridge, UK: Cambridge University Press.

- 2007. Legitimating Usurpation: Historical Revisions Under the Ming Yongle Emperor (r. 14021424). In The Legitimation of New Orders: Case Studies in World History, edited by Philip Yuen-sang Leung, 75-117. Hong Kong: Chinese University Press.

Church, Sally K. 2004. The Giraffe of Bengal: A Medieval Encounter in Ming China. The Medieval History Journal 7 (1):1-37.

Clark, Ian. 2009. Towards an English School Theory of Hegemony. European Journal of International Relations 15 (2):203-28.

Cooley, Alexander. 2005. Logics of Hierarchy: The Organization of Empires, States, and Nations in Transit. Ithaca, NY: Cornell University Press. 
Cooley, Alexander, and Daniel H. Nexon. 2016. Interpersonal Networks and International Security. In The New Power Politics: Networks and Transnational Security Governance, edited by Deborah Avant and Oliver Westerwinter, 74-102. New York: Oxford University Press.

Ditmanson, Peter. 2007. Venerating the Martyrs of the 1402 Usurpation: History and Memory in the Mid and Late Ming Dynasty. T'oung Pao 93 (1):110-58.

Donnelly, Jack. 2015. The Discourse of Anarchy in IR. International Theory 7 (3):393-425.

Dreyer, Edward L. 2007. Zheng He: China and the Oceans in the Early Ming Dynasty, 1405-1433. New York: Pearson Longman.

Early, Bryan R. 2014. Exploring the Final Frontier: An Empirical Analysis of Global Civil Space Proliferation. International Studies Quarterly 58 (1):55-67.

Eyre, Dana P., and Mark C. Suchman 1996. Status, Norms, and the Proliferation of Conventional Weapons: An Institutional Theory Approach. In The Culture of National Security: Norms and Identity in World Politics, edited by Peter J. Katzenstein, 79-113. New York: Columbia University Press.

Finlay, Robert 1991. The Treasure-Ships of Zheng He: Chinese Maritime Imperialism in the Age of Discovery. Terrae Incognitae 23 (1):1-12.

- 2008. The Voyages of Zheng He: Ideology, State Power, and Maritime Trade in Ming China. Journal of the Historical Society 8 (3):327-47.

Finnemore, Martha 1996. National Interests in International Society. Ithaca, NY: Cornell University Press. Fursenko, Aleksandr, and Timothy Naftali. 2007. Khrushchev's Cold War: The Inside Story of an American Adversary. New York: W.W. Norton and Company.

Gaddis, John Lewis. 2006. The Cold War: A New History. New York: Penguin.

Galtung, Johan 1971. A Structural Theory of Imperialism. Journal of Peace Research 8 (2):81-117.

Gilady, Lilach. 2006. Conspicuous Waste in International Relations. PhD Dissertation, Yale University. 2017. The Price of Prestige: Conspicuous Consumption in International Relations. Chicago, IL: Chicago University Press.

Gilpin, Robert 1981. War and Change in World Politics. New York: Cambridge University Press.

Go, Julian. 2008. Global Fields and Imperial Forms: Field Theory and the British and American Empires. Sociological Theory 26 (3):201-27.

Go, Julian, and Monica Krause. 2016. Fielding Transnationalism: An Introduction. In Fielding Transnationalism, edited by Julian Go and Monica Kruase, 6-30. Malden, MA: John Wiley and Sons.

Goddard, Stacie E. 2008/2009. When Right Makes Might: How Prussia Overturned the European Balance of Power. International Security 33 (3):110-42.

Goddard, Stacie E., and Daniel H. Nexon. 2016. The Dynamics of Global Power Politics: A Framework for Analysis. Journal of Global Security Studies 1 (1):4-18.

Goldstone, Jack A. 2000. The Rise of the West-or Not? A Revision to Socio-economic History. Sociological Theory 18 (2):175-94.

Guzzini, Stefano 1993. Structural Power: The Limits of Neorealist Power Analysis. International Organization 47 (3):443-78.

Heppenheimer, Thomas A. 1999. The Space Shuttle Decision. NASA History Series, NASA SP-4221. Available at $<$ https://history.nasa.gov/SP-4221/contents.htm>.

Hobson, John M., and J.C. Sharman. 2005. The Enduring Place of Hierarchy in World Politics: Tracing the Social Logics of Hierarchy and Political Change. European Journal of International Relations 11 (1): 63-98.

Hoffman, Philip T. 2015. Why Did Europe Conquer the World? Princeton, NJ: Princeton University Press. Hucker, Charles O. 1998. Ming Government. In Cambridge History of China, Volume 8, The Ming Dynasty, 1368-1644, Part II, edited by F.W. Mote and D. Twitchett, 9-105. Cambridge: Cambridge University Press.

Hui, Victoria Tin-bor. 2005. War and State Formation in Ancient China and Early Modern Europe. New York: Cambridge University Press.

Hurd, Ian. 2005. The Strategic Uses of Liberal Internationalism: Libya and the UN Sanctions Regime, 1992-2003. International Organization 59 (3):495-526. 
Humphreys, Macarta, and Alan M. Jacobs. 2015. Mixing Methods: A Bayesian Approach. American Political Science Review 109 (4):653-73.

Ikenberry, G. John. 2011. Liberal Leviathan: The Origins, Crisis, and Transformation of the American World Order. Princeton, NJ: Princeton University Press.

Kang, David C. 2010. East Asia Before the West: Five Centuries of Trade and Tribute. New York: Columbia University Press.

Khong, Yuen Foong. 2013. The American Tributary System. The Chinese Journal of International Politics $6(1): 1-47$.

Kloc, Joe. 2012. The Case of the Missing Moon Rocks. Self-published with The Atavist.

Koivisto, Marjo, and Tim Dunne. 2009. Crisis, What Crisis? Liberal Order Building and World Order Conventions. Millennium: Journal of International Studies 38 (3):615-40.

Krieger, Miriam, Shannon L.C. Souma, and Daniel Nexon. 2016. US Military Diplomacy in Practice. In Diplomacy and the Making of World Politics, edited by Ole Jacob Sending, Vincent Pouliot, and Iver B. Neumann, 220-55. Cambridge, UK: Cambridge University Press.

Lake, David A. 2009. Hierarchy in International Relations. Ithaca, NY: Cornell University Press.

Landes, David S. 1999. The Wealth and Poverty of Nations: Why Some Are So Rich and Some So Poor. New York: WW Norton and Company.

Larson, Deborah Welch, and Alexei Shevchenko. 2010. Status Seekers: Chinese and Russian Responses to US Primacy. International Security 3 (4):63-95.

Launius, Roger D. 2012. Why Go to the Moon? The Many Faces of Lunar Policy. Acta Astronautica 70: $165-75$.

Lee, Ji-Young. 2013. Diplomatic Ritual as a Power Resource: The Politics of Asymmetry in Early Modern Chinese-Korean Relations. Journal of East Asian Studies 13 (2):309-36.

- 2016. China's Hegemony: Four Hundred Years of East Asian Domination. New York: Columbia University Press.

Lemke, Douglas. 2002. Regions of War and Peace. Cambridge, UK: Cambridge University Press.

Logsdon, John M. 2010. John F. Kennedy and the Race to the Moon. New York: Palgrave MacMillan.

- 2011. A New Approach to Human Spaceflight. Space Policy 27 (1):153-56

McAdam, Doug, Sidney Tarrow, and Charles Tilly. 2001. Dynamics of Contention. New York: Cambridge University Press.

McCourt, David M. 2016. Practice Theory and Relationalism as the New Constructivism. International Studies Quarterly 60 (3):475-85.

McDonald, Patrick J. 2015. Great Powers, Hierarchy, and Endogenous Regimes: Rethinking the Domestic Causes of Peace. International Organization 69 (3):557-88.

McDougall, Walter A. 1985. ... The Heavens and the Earth: A Political History of the Space Age. New York: Basic Books.

Muir-Harmony, Teasel. 2014. Project Apollo, Cold War Diplomacy, and the American Framing of Global Interdependence. PhD Dissertation, Massachusetts Institute of Technology.

Musgrave, Paul, and Daniel Nexon. 2013. States of Empire: Liberal Ordering and Imperial Relations. In Liberal World Order, edited by Timothy Dunne and Trine Flockhart, 211-30. Oxford: Oxford University Press.

Needham, Joseph. 1971. Science and Civilisation in China, Vol. 4, Physics and Physical Technology, Part III: Civil Engineering and Nautics. Cambridge, UK: Cambridge University Press.

Neumann, Iver B. 2011. Status Is Cultural: Durkheimian Poles and Weberian Russians Seek Great-Power Status. In Status in World Politics edited by T.V. Paul, Deborah W. Larson, and William Wohlforth, 85114. Cambridge, UK: Cambridge University Press.

Nexon, Daniel H. 2009. The Struggle for Power in Early Modern Europe: Religious Conflict, Dynastic Empires, and International Change. Princeton, NJ: Princeton University Press.

Nexon, Daniel H. and Iver B. Neumann 2017. Hegemonic-Order Theory: A Field-Theoretic Account. European Jouranl of International Relations. Published electronically 4 July. https://doi.org/10.1177/ 1354066117716524. 
Nexon, Daniel, and Thomas Wright. 2007. What's at Stake in the American Empire Debate. American Political Science Review 101 (2):253-71.

Onea, Tudor A. 2014. Between Dominance and Decline: Status Anxiety and Great Power Rivalry. Review of International Studies 40 (1):125-52.

Peterson, M.J. 1997. The Use of Analogies in Developing Outer Space Law. International Organization 51 (2):245-74.

Pouliot, Vincent. 2011. Setting Status in Stone: The Negotiation of International Institutional Privileges. In Status in World Politics, edited by T.V. Paul, Deborah W. Larson, and William Wohlforth, 192-218. Cambridge, UK: Cambridge University Press.

Pouliot, Vincent, and Frédéric Mérand. 2012. Boudieu's Concepts. In Bourdieu in International Relations: Rethinking Key Concepts in IR, edited by Rebecca Adler-Nissen, 24-44. New York: Routledge.

$\mathrm{Pu}$, Xiaoyu, and Randall L. Schweller. 2011. Status Signaling, Multiple Audiences, and China's BlueWater Naval Ambitions. In Status in World Politics, edited by T.V. Paul, Deborah W. Larson, and Willam Wohlforth, 141-64. Cambridge, UK: Cambridge University Press.

Renshon, Jonathan. 2016. Status Deficits and War. International Organization 70 (3):513-50.

Reus-Smit, Christian 1997. Constructing Anarchy: The Constitutional Structure of International Society and the Nature of Fundamental Institutions. International Organization 51 (4):555-89.

Rossabi, Morris 1998. The Ming and Inner Asia. Cambridge History of China, Vol. 8, The Ming Dynasty, 1368-1644, Part II. Edited by Frederick W. Mote and Denis Twitchett, 221-71. Cambridge, UK: Cambridge University Press.

Rupprecht, Tobias. 2015. Soviet Internationalism after Stalin: Interaction and Exchange between the USSR and Latin America during the Cold War. Cambridge, UK: Cambridge University Press, 2015.

Saunders, Frances Stonor. 2013. The Cultural Cold War: The CIA and the World of Arts and Letters. New York: The New Press.

Savage, Mike, Alan Warde, and Fiona Devine. 2005. Capitals, Assets, and Resources: Some Critical Issues. The British Journal of Sociology 56 (1):31-46.

Sheehan, Michael. 2007. The International Politics of Space. New York: Routledge.

Smith, Cameron, and Evan T. Davies. 2012. Emigrating Beyond Earth: Human Adaptation and Space Colonization. New York: Springer Science and Business Media.

Steinberg, Gerald M. 1987. Large-Scale National Projects as Political Symbols: The Case of Israel. Comparative Politics 19 (3):331-46.

Stine, Deborah D. 2009. The Manhattan Project, the Apollo Program, and Federal Energy Technology R\&D Programs: A Comparative Analysis. Washington, DC, Congressional Research Service, Library of Congress. Available at <https://fas.org/sgp/crs/misc/RL34645.pdf>.

Tilly, Charles. 1995. To Explain Political Processes. American Journal of Sociology 100 (6):1594-610.

- 1997. Means and Ends of Comparison in Macrosociology. Comparative Social Research 16:43-53.

Towns, Ann. 2009. The Status of Women as a Standard of "Civilization." European Journal of International Relations 15 (4):681-706.

Van Dyke, Vernon. 1964. Pride and Power: The Rationale of the Space Program. Urbana: University of Illinois Press.

Vitalis, Robert. 2015. White World Order, Black Power Politics: The Birth of American International Relations. Ithaca, NY: Cornell University Press.

Volgy, Thomas J., and Stacey Mayhall. 1995. Status Inconsistency and International War: Exploring the Effects of Systemic Change. International Studies Quarterly 39 (1):67-84.

Von Eschen, Penny. 2009. Satchmo Blows Up the World: Jazz Ambassadors Play the Cold War. Cambridge, MA: Harvard University Press.

Vucetic, Radina. 2011. Soviet Cosmonauts and American Astronauts in Yugoslavia. In Soviet Space Culture: Cosmic Enthusiasm in Socialist Societies, edited by Eva Maurer, Julia Richers, Monica Ruthers, and Carmen Scheide, 188-205. New York: Palgrave Macmillan.

Vucetic, Srdjan. 2011. The Anglosphere: A Genealogy of a Racialized Identity in International Relations. Stanford, CA: Stanford University Press. 
Wade, Geoff. 2008. Engaging the South: Ming China and Southeast Asia in the Fifteenth Century. Journal of the Economic and Social History of the Orient 51 (4):578-638.

Wallerstein, Immanuel Maurice. 2004. World-Systems Analysis: An Introduction. Durham, NC: Duke University Press.

Waltz, Kenneth. 1979. Theory of International Politics. New York: Addison-Wesley.

Wang, Yuan-kang. 2012. Managing Regional Hegemony in Historical Asia: The Case of Early Ming China. The Chinese Journal of International Politics 5 (2):129-53.

Wendt, Alexander, and Daniel Friedheim. 1995. Hierarchy Under Anarchy: Informal Empire and the East German State. International Organization 49 (4):689-721.

Westad, Odd Arne. 2007. The Global Cold War: Third World Interventions and the Making of Our Times. Cambridge, UK: Cambridge University Press.

Wiesner, Jerome. 1961. "Space Frontiers." Reprinted in New Frontiers of the Kennedy Administration: The Texts of the Task Force Reports Prepared for the President. Washington, DC: Public Affairs Press. Available via HeinOnline.

Wohlforth, William C. 2009. Unipolarity, Status Competition, and Great Power War. World Politics 61 (1): 28-57.

Wyatt, James C.Y. 2008. The Giraffe as the Mythical Qilin in Chinese Art. Metropolitan Museum Journal 43:111-15.

Wang, Gungwu. 1998. Ming Foreign Relations: Southeast Asia. In The Cambridge History of China, Vol. 8, edited by Denis C. Twitchett, and Frederick W. Mote, 301-32. New York: Cambridge University Press.

Zakaria, Fareed. 2012. The Post-American World: Release 2.0. New York: Norton and Company.

Zarakol, Ayşe. 2011. After Defeat: How the East Learned to Live with the West. Cambridge, UK: Cambridge University Press.

Zaks, Sherry. 2017. Relationships Among Rivals: A Framework for Analyzing Contending Hypotheses in Process-Tracing Research. Political Analysis 25 (3):344-62.

Zhang, Feng. 2015. Chinese Hegemony: Grand Strategy and International Institutions in East Asian History. Stanford, CA: Stanford University Press.

Zhang, Xiaojun. 2004. Land Reform in Yang Village: Symbolic Capital and the Determination of Class Status. Modern China 30 (1):3-45. 